\title{
Clinical Studies on Widespread Discoid Lupus \\ Erythematosus
}

\author{
— Relationship of Discoid Lupus Erythematosus \\ to Systemic Lupus Erythematosus -
}

\begin{abstract}
Kazuo SASAOKA, Masaharu RIKIMARU, Isamu TAKAHASHI, Sodao ANAN, Hideaki YAMAURA, and Tomio AKIYAMA*
\end{abstract}

\author{
Department of Dermatology, Nagasaki University \\ School of Medicine, Nagasaki, Japan
}

Received for Publication, December 7, 1976

\begin{abstract}
To clarify the relationship between discoid lupus erythematosus (DLE) and systemic lupus erythematosus (SLE), we have studied clinically 15 patients with widespread DLE. The patients were divided into four grades according to the extent of their cutaneous lesions.

Thirteen of 15 patients had widespread chronic discoid lesions as their initial manifestation. The ratio of females to males was approximately $1: 1$. The average age at onset was 39 yerars old, and the most common age was between 20 and 40 years.

In four of five patients (all in Grade IV and men), the cutaneous lesions appeared after the age of 40 years. In many patients with widespread DLE, clinical and laboratory abnormalities were observed, such as fever, arthralgia, fatigability, photosensitivity, leucopenia, elevated erythrocyte sedimentation rate, hypergammaglobulinemia, proteinuria, but the incidence of LE cells, positive LE test, chronic BFP was much less in widespread DLE than SLE. Two patients (Grade IV) fulfilled the ARA criteria for SLE.

These findings suggest that DLE and SLE are closely related diseases.
\end{abstract}

*笹岡和夫, 力丸正治, 高橋 勇

阿南貞雄, 山浦英明, 䅖山富雄 


\section{INTRODUCTION}

Lupus erythematorsus (LE) can be divided roughly into two types, namely, chronic discoid lupus erythematosus (DLE) in localized to the skin and systemic lupus erythematosus (SLE) in view of the dermatological and immunological findings.

Actually, however, it is a fact that there exist cases changing from one type to another and also cases of an intermediate type that cannot clearly differentiate these two types.

Selecting such cases of widespread DLE (W-DLE) ${ }^{17) 18}$ in which typical discoid lesions develop extensively in regions other than the face and making a complete study of these cases from various field will be a helpful mean to investigate whether these two types of diseases are essentially identical.

From such a viewpoint, we classified 15 cases of this type of disease into four degrees according to the degree of the extent of skin lesions and made clinical studies, including laboratory findings and histopathological findings.

\section{MATERIALS AND METHODS}

\section{Subject}

Fifteen patients were collected at the Nagasaki University School Hospital. All cases of W-DLE had typical discoid lesions with erythema, hyperkeratosis and atrophy as its main features and with pigmentation, depigmentation and teleangiectasis in some cases developed over the trunk and extremities other than the face, head, auricles and neck. The case of localized DLE (L-DLE) in which discoid lesions develop locally on the face was not included in the subjects.

The type of the disease called W-DLE, corresponds to "chronic disseminated type" according to classification of MICHELSON ${ }^{13)}$ and to "generalized type of DLE". according to that of PASCHER ${ }^{16)}$.

\section{Classification of patients with W-DLE}

All cases were classified into four grades, Grade I to Grade IV according to the degree of the extent of the lesion in order to examine the relationspip between discoid lesions, general manifestations and laboratory findings (Table 1). The site of distribution of discoid lesions was divided into two areas. The circle in Table 1 indicates the extent of discoid lesions and one with two circles in total was designated as Grade I, three as Grade II, four as Grade III and five or more as Grade IV.

No. 1 and No. 2 were classified into Grade I, four cases of No.3-No.6 into Grade II, four cases of No.7-No.10 into Grade III and five cases of No.11-No.15 into Grade IV. Grade I refers to the case in which no difference is found in the scope of distribution of discoid lesions from L-DLE and Grade IV to the case in which skin lesions are disseminated all over the body. 
Table 1. Classification of Patients and the Extent of Discoid Lesions.

\begin{tabular}{|c|c|c|c|c|c|c|c|c|}
\hline \multirow{2}{*}{$\begin{array}{l}\text { Patient } \\
\text { No. }\end{array}$} & \multirow[b]{2}{*}{ Sex } & \multirow[b]{2}{*}{ Age } & \multicolumn{2}{|c|}{ Exposed Area } & \multicolumn{2}{|c|}{ Clothed Area } & \multirow{2}{*}{$\begin{array}{c}\text { Number } \\
\text { of } \mathrm{O}\end{array}$} & \multirow[b]{2}{*}{ Grade } \\
\hline & & & $\begin{array}{l}\text { face, head, } \\
\text { neck, ear }\end{array}$ & fingers, toes & extremities & trunk & & \\
\hline 1 & M & 44 & 0 & & & 0 & 2 & I \\
\hline 2 & $\mathrm{~F}$ & 40 & 0 & & 0 & & 2 & I \\
\hline 3 & M & 40 & 00 & & 0 & & 3 & II \\
\hline 4 & $\mathrm{~F}$ & 56 & 0 & 0 & & 0 & 3 & $\mathbb{I}$ \\
\hline 5 & $\mathrm{~F}$ & 65 & 0 & 0 & 0 & & 3 & II \\
\hline 6 & M & 40 & 0 & & 0 & 0 & 3 & II \\
\hline 7 & $\mathrm{~F}$ & 26 & 00 & 0 & 0 & & 4 & III \\
\hline 8 & M & 46 & 0 & 0 & 0 & 0 & 4 & III \\
\hline 9 & $\mathrm{~F}$ & 44 & 00 & & 0 & 0 & 4 & $\mathbb{I I}$ \\
\hline 10 & $\mathrm{~F}$ & 42 & & 0 & 0 & 00 & 4 & III \\
\hline 11 & M & 67 & 00 & 0 & 0 & 0 & 5 & IV \\
\hline 12 & M & 64 & 00 & 0 & 0 & 0 & 5 & N \\
\hline 13 & M & 56 & 0 & 0 & 0 & 00 & 5 & IV \\
\hline 14 & M & 40 & 00 & & 0 & 00 & 5 & IN \\
\hline 15 & $\mathrm{~F}$ & 43 & 00 & 0 & 0 & 00 & 6 & IN \\
\hline
\end{tabular}

\section{Methods}

Studies were made on the clinical features (sex, age of onset, duration of skin lesions, predisposing factors), laboratory findings (leucocyte count, erythrocyte sedimentation rate, proteinuria, serum proteins, RA test, chronic BFP reaction, LE-cell test, LE-test), histopathological findings, therapeutic effect and diagnostic criteria for SLE.

\section{RESULTS}

\section{1) Clinical features}

Clinical features of W-DLE were summarized in Table 2.

Sex : While there was not much difference in the sex ratio between males and females, there were more males in Grade IV.

Age of onset of skin lesions : About 60 percent of all cases experienced onset of skin lesions in their $20 \mathrm{~s}$ to $30 \mathrm{~s}$. The mean age of onset was 39 years old (44 years for men and 34 years for women). Women showed a relatively wide range of distribution from their $20 \mathrm{~s}$ to $50 \mathrm{~s}$; however, men showed two peaks with one in their $30 \mathrm{~s}$ and the other in their 50s downward ; moreover, in the case where skin lesions develop in the elderly people aged 50 years, they are of the Grade IV in which skin lesions develop all over the body. (Table 3)

Duration of discoid lesions : Discoid lesions have been present for five years or more in all cases except one case (No.10) in Grade I to Grade III. Most cases in Grade II and Grade III show that skin lesions occured first in the face took several years or more to expand gradually to other regions. 
Table 2. Clinical Features of W-DLE

\begin{tabular}{|c|c|c|c|c|c|c|c|c|c|c|}
\hline \multirow[b]{2}{*}{ Grade } & \multirow[b]{2}{*}{ No. } & \multirow[b]{2}{*}{ Sex } & \multirow[b]{2}{*}{ Age } & \multicolumn{3}{|c|}{ Cutaneous Lesions } & \multicolumn{3}{|c|}{ General Signs } & \multirow{2}{*}{$\begin{array}{l}\text { Predisposing } \\
\text { Factors } \\
\text { (Complication) }\end{array}$} \\
\hline & & & & $\begin{array}{l}\text { butterfly } \\
\text { rash }\end{array}$ & $\begin{array}{c}\text { discoid } \\
\text { lupus }\end{array}$ & alopecia & fever & arthralgia & malaise & \\
\hline I & 1 & $\mathrm{M}$ & 44 & & 0 & & & & & \\
\hline 1 & 2 & $\mathrm{~F}$ & 40 & 0 & 0 & & & & & pregnancy \\
\hline II & 3 & $\mathrm{M}$ & 40 & & 0 & & & & & sunburn \\
\hline II & 4 & $\mathrm{~F}$ & 56 & & 0 & & & 0 & 0 & (gastric ulcer) \\
\hline $\mathbb{I}$ & 5 & $\mathrm{~F}$ & 65 & & O & 0 & & & & (arteriosclerosis) \\
\hline II & 6 & M & 40 & O & 0 & & 0 & & 0 & sunburn \\
\hline $\mathbb{1 1}$ & 7 & $\mathrm{~F}$ & 26 & O & 0 & & 0 & O & 0 & Penicillin \\
\hline III & 8 & M & 46 & & 0 & & & & & rgy) \\
\hline III & 9 & $\mathrm{~F}$ & 44 & & O & 0 & 0 & 0 & O & (polymyositis) \\
\hline III & 10 & $\mathrm{~F}$ & 42 & & 0 & & & & & \\
\hline IV & 11 & $\mathrm{M}$ & 67 & 0 & $\bigcirc$ & & 0 & & 0 & overwork \\
\hline IV & 12 & M & 64 & 0 & O & 0 & 0 & & 0 & \\
\hline IV & 13 & $\mathrm{M}$ & 56 & & 0 & & 0 & 0 & 0 & \\
\hline IV & 14 & M & 40 & & 0 & 0 & 0 & 0 & 0 & overwork \\
\hline N & 15 & $\mathrm{~F}$ & 43 & 0 & 0 & 0 & 0 & 0 & 0 & sunburn \\
\hline
\end{tabular}

Table 3. Age of Onset of Skin Lesions

\begin{tabular}{|c|c|c|c|c|c|c|c|}
\hline Grade $\begin{array}{c}\text { Age } \\
\text { (years) }\end{array}$ & -19 & $20-29$ & $30-39$ & $40-49$ & $50-59$ & $60-$ & $\begin{array}{c}\text { Average } \\
\text { Years }\end{array}$ \\
\hline $\begin{array}{l}\text { I } \\
\text { II } \\
\text { III } \\
\text { IV }\end{array}$ & & $\begin{array}{c}0 \\
0\end{array}$ & $0_{0}^{0}$ & $\begin{array}{l}0 \\
0\end{array}$ & 0 & & $\begin{array}{l}30 \\
38 \\
31 \\
50\end{array}$ \\
\hline $\begin{array}{c}\text { Case } \\
\underset{(\%)}{\text { umbers }}\end{array}$ & $\begin{array}{c}0 \\
(0)\end{array}$ & $\begin{array}{c}4 \\
(26.6)\end{array}$ & $\begin{array}{c}5 \\
(33.3)\end{array}$ & $\begin{array}{c}2 \\
(13.3)\end{array}$ & $\begin{array}{c}2 \\
(13.3)\end{array}$ & $\begin{array}{c}2 \\
(13.3)\end{array}$ & 15 \\
\hline
\end{tabular}

By contrast, skin lesions of Grade IV seen in elderly persons were characterized by developing all over the body in a relatively short period of time (1-2 years). Most cases started with discoid lesions, but there were some cases, where general manifestations such as fever, arthralgia and malaise preceded skin lesions as in No.7 and No.14 (Fig.1).

Cutaneous manifestations: The case of long-standing discoid lesions in patients with W-DLE showed a strong tendency to depigmentation and atrophy. As for other skin manifestctions, there were observed typical butterfly rash in 6 out of 15 cases and alopecia in 5 cases.

Evident photosensitivity was observed in 4 out of 15 cases, while Raynaud's phenomenon often seen in SLE was not found at all in W-DLE.

General manifestions : General manifestations such as fever, arthralgia and malaise were not observed in Grade I, but found in half of the cases of Grade II and Grade III and all 


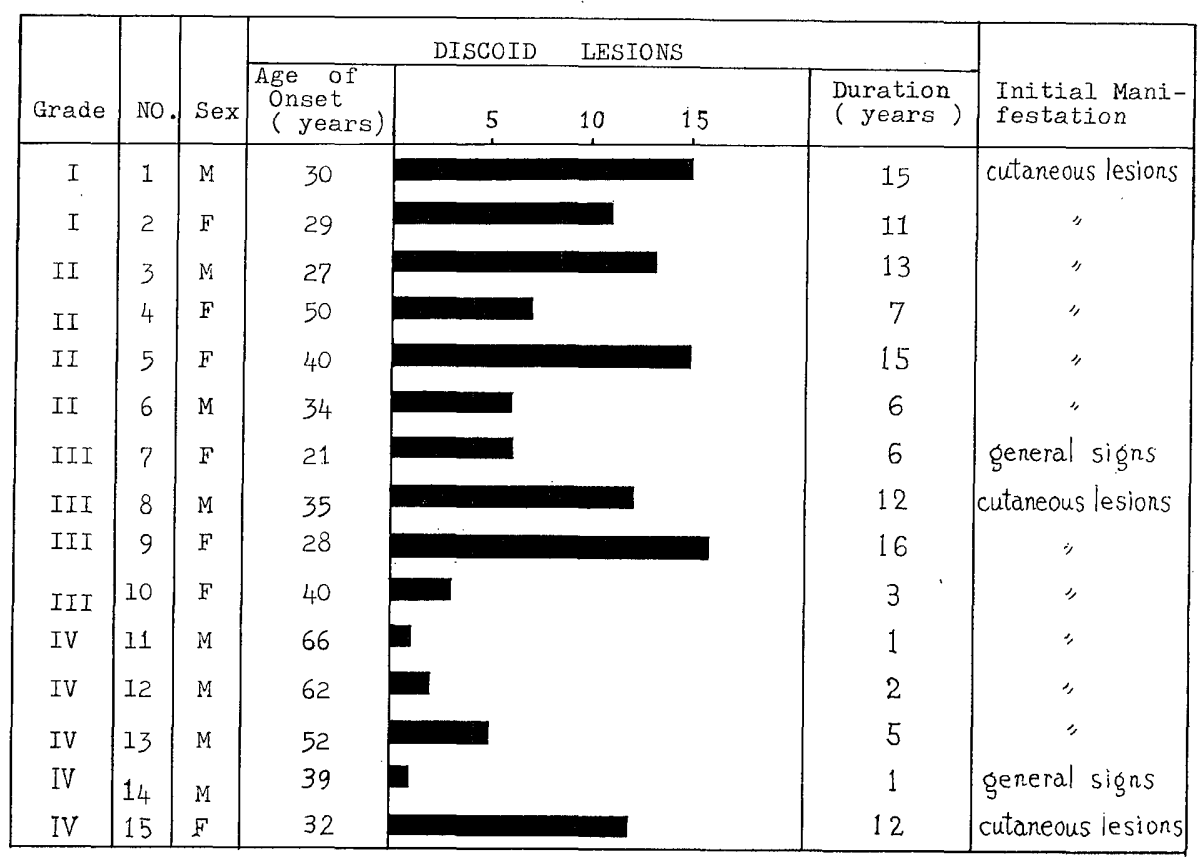

Fig 1. Age of Onset and Duraton of Sikn lesions

cases of Grade IV. General manifestations tend to appear in large numbers in proportion to the enlargement of skin lesions; however, they usually disappear as skin lesions and laboratory results are improved following administration of steroids and immunosuppressive drugs.

Predisposing factors and complications : As predisposing factors and complications of this disease, mention can be made of sunburn, overwork, drugs, pregnancy, polymyositis and so forth ; above all, exposure to sunlight is the foremost predisposing factor.

\section{2) Laboratory Findings}

Laboratory findings for fifteen cases of W-DLE were as shown in Table 4.

Leucocyte and lymphocyte count: About half of the cases showed leucopenia with leucocyte count $4000 / \mathrm{mm}^{3}$ or less; this tendency was particularly strong in Grade III and Grade IV. However, lymphopenia with the absolute number of lymphocyte less than $1000 / \mathrm{mm}^{3}$ was found in only two cases (13.3\%).

Erythrocyte sedimentation rate (ESR) : ESR was normal in Grade I, but it was moderately increased in about half of the cases of Grade II and markedly increased in all cases of Grade IV.

Proteinuria: Proteinuria was observed in only small number of cases of Grade I to Grade III, however, with the Grade IV, there appeared various types ranging from trace in all cases to high-degree proteinuria in some cases (No.14, No.15). Incidentally, No. 14 had subacute glomerulonephritis and No.15 lupus nephritis in kidney biopsy. 
Table 4. Laboratory Findings

\begin{tabular}{|c|c|c|c|c|c|c|c|c|c|c|c|}
\hline Grade & No. & $\begin{array}{l}\text { WBC }\left(/ \mathrm{mm}^{3}\right) \\
\text { (Lymphocyte) }\end{array}$ & $\begin{array}{c}\mathrm{ESR} \\
(\mathrm{mm} / \mathrm{h})\end{array}$ & $\begin{array}{l}\text { Protei- } \\
\text { nuria }\end{array}$ & $\left|\begin{array}{l}\text { T.P } \\
\text { (g/dl) }\end{array}\right|$ & $\mathrm{A} / \mathrm{G}$ & $\frac{\gamma-\mathrm{Gl} .}{(\%)}$ & $\begin{array}{l}\text { RA } \\
\text { test }\end{array}$ & $\begin{array}{c}\text { chronic } \\
\text { BFP }\end{array}$ & $\begin{array}{l}\mathrm{LE} \\
\text { cells }\end{array}$ & $\begin{array}{l}\text { LE } \\
\text { test }\end{array}$ \\
\hline I & 1 & $10,200(2,040)$ & 16 & - & 7.5 & 1.4 & 15.2 & - & N.D & N.D & N.D \\
\hline 1 & 2 & $6,900(2,270)$ & 18 & - & 7.3 & 0.9 & 32.3 & - & " & $"$ & - \\
\hline II & 3 & $6,400(2,430)$ & 6 & - & 7.5 & 1.4 & 20.7 & - & - & " & - \\
\hline II & 4 & $4,100(1,510)$ & 38 & - & 8.0 & 1.3 & 21.6 & + & - & " & - \\
\hline II & 5 & $4,400(1,760)$ & 24 & - & 7.4 & 1.3 & 16.3 & - & N.D & - & N.D \\
\hline II & 6 & $6,300(2,640)$ & 43 & + & 7.8 & 1.2 & 24.1 & + & - & - & - \\
\hline III & 7 & $4,100(900)$ & 25 & \pm & 8.1 & 0.7 & 29.0 & + & - & - & - \\
\hline III & 8 & $5,800(2,320)$ & 5 & - & 6.9 & 1.8 & 13.3 & - & N.D & N.D & N.D \\
\hline $\mathbb{I I}$ & 9 & $5,800(2,200)$ & 32 & - & 6.8 & 1.0 & 26.0 & - & - & - & - \\
\hline III & 10 & $2,600(750)$ & 23 & - & 7.7 & 1.2 & 25.0 & + & - & - & + \\
\hline N & 11 & $4,200(2,600)$ & 71 & + & 7.3 & 1.2 & 21.3 & - & + & - & - \\
\hline IV & 12 & $7,000(2,450)$ & 84 & \pm & 5.7 & 1.1 & 26.6 & + & - & - & - \\
\hline IV & 13 & $5,700(2,170)$ & 39 & \pm & 7.5 & 1.5 & 29.9 & - & - & + & + \\
\hline IV & 14 & $3,200(1,060)$ & 63 & $+\sim H$ & 8.2 & 1.0 & 31.0 & - & - & - & - \\
\hline IV & 15 & $4,100(1,350)$ & 81 & $H \sim H$ & 8.4 & 0.7 & 35.6 & + & - & - & - \\
\hline
\end{tabular}

N.D $\cdots \cdots \cdot \cdots \cdot$ not done

Total serum protein and gammaglobulin: Total serum protein was normal in Grade I; it was increased $(8.0 \mathrm{~g} / \mathrm{dl}$ or more) in one case each of Grade II and Grade III and two cases of Grade IV. Gammaglobulin value differed between men and women. In the case of women, there was observed hypergammaglobulinemia in all cases except one case of Grade II ; however in men, few showed hypergammaglobulinemia in Grade I to Grade III and only in Grade IV did the increase in gammaglobulin value become prominent in proportion to the extent of skin lesions.

RA test, chronic BFP : Not even one case gave a positive reaction to RA (latex-fixation) test in Grade I, but the test was positive in about half of the cases of Grade II to Grade IV. Chronic BFP (biological false positive reaction) was found in only one case (No.11) of Grade IV.

$L E$ cell test, LE test : LE-cell preparation was made by the two hour-clot method. LEcell test was performed only in antinuclear antibody positive cases, but only one case (No. 13) of Grade IV gave a positive reaction temporarily to the test.

The occurrence of positive LE test was also low, and LE test was positive only in one case each of Grade III and Grade IV.

\section{3) Histopathological Findings}

Grade I and Grade II were characterized by marked hyperkeratosis and keratotic plugging in epidermis and perivascular and periappendageal lymphocytic infiltration in corium ; this findings resembles the histopathology of L-DLE.

Grade IV in its late stage showed findings very close to the tissue pattern of SLE, teaturing marked epidermal atrophy and liquefaction degeneration in epidermis with mild 
lymphocytic infiltration, edema, capillary ectasia, swelling and degeneration of collagen bundles in corium.

\section{4) Changes of skin lesions and therapeutic effects}

As shown in Table 5, topical application of steroid ointments was done to Grade I to see improvement in skin lesions; Cases of Grade II to Grade IV with general manifestaions were all placed on the single or combined administration of oral steroids or immunosuppresive drugs to see improvement in varying degrees in skin lesions as well as general manifestations and laboratory findings. There was not even one case of death.

A change in the grade following the treatment was found in one case of Grade II (Grade II $\rightarrow$ I), two cases in Grade III (Grade III $\rightarrow$ II) and one case in Grade IV (Grade $\mathrm{IV} \rightarrow \mathrm{II})$.

5) Diagnosis of the patients with W-DLE by ARA criteria for SLE

Cases of W-DLE were studied by the ARA criteria for SLE. ${ }^{4}$ (Table 6) Two cases in

Table 5. Clinical and Laboratory Effects due to Therapy

\begin{tabular}{|c|c|c|c|c|c|c|}
\hline \multirow[b]{2}{*}{ Grade } & \multirow[b]{2}{*}{ No. } & \multirow[b]{2}{*}{ therapy* } & \multicolumn{3}{|c|}{ Therapeutic effects } & \multirow{2}{*}{$\begin{array}{l}\text { skin lesions } \\
\text { due to therapy }\end{array}$} \\
\hline & & & $\begin{array}{l}\text { skin } \\
\text { lesions }\end{array}$ & $\begin{array}{l}\text { general } \\
\text { signs }\end{array}$ & $\begin{array}{l}\text { laboratory } \\
\text { findings }\end{array}$ & \\
\hline I & 1 & topical & + & & - & no change \\
\hline I & 2 & " & + & & - & " \\
\hline II & 3 & " & + & & - & " \\
\hline $\mathbb{I}$ & 4 & $\begin{array}{c}\text { topical } \\
\text { systemic(ST) }\end{array}$ & + & + & + & $\mathbb{I} \rightarrow \mathrm{I}$ \\
\hline II & 5 & topical & - & & - & no change \\
\hline II & 6 & $\begin{array}{l}\text { systemic } \\
\text { (ST) }\end{array}$ & + & + & H & " \\
\hline III & 7 & $\begin{array}{l}\text { systemic } \\
\text { (ST) }\end{array}$ & + & + & + & " \\
\hline III & 8 & topical & + & & - & " \\
\hline III & 9 & $\begin{array}{l}\text { systemic } \\
\text { (ST.ISD) }\end{array}$ & H & H & + & $\mathbb{I I} \rightarrow \mathbb{I}$ \\
\hline III & 10 & " & + & & + & $\mathbb{I I} \rightarrow \mathbb{I}$ \\
\hline IV & 11 & $"$ & $H$ & $H$ & + & no change \\
\hline N & 12 & $\begin{array}{l}\text { systemic } \\
\text { (ISD) }\end{array}$ & $H$ & H & + & " \\
\hline IV & 13 & $\begin{array}{c}\text { systemic } \\
(\mathrm{ST}, \mathrm{ISD})\end{array}$ & $H$ & $H$ & H & $\mathbb{N} \rightarrow \mathbb{I}$ \\
\hline IV & 14 & " & + & $H$ & $H$ & no change \\
\hline N & 15 & $\begin{array}{l}\text { systemic } \\
\text { (ST) }\end{array}$ & + & $H$ & H & " \\
\hline
\end{tabular}

*topical : topical application of steroids

systemic $\left\{\begin{array}{l}\mathrm{ST}: \text { steroids } \\ \mathrm{ISD}: \text { immunosuppressive drugs (Azathioprine) }\end{array}\right.$ 
Table 6. Diagnosis of W-DLE by ARA Criteria for SLE

\begin{tabular}{|c|c|c|c|c|c|}
\hline Grade & No. & & $\begin{array}{l}\text { ARA criteria } \\
\text { for S L E }\end{array}$ & $\begin{array}{l}\text { No. of ARA } \\
\text { criteria }\end{array}$ & Diagnosis \\
\hline I & 1 & 1) & discoid lupus & 1 & non SLE \\
\hline 1 & 2 & 1) & $\begin{array}{l}\text { discoid lupus } \\
\text { facial erythema }\end{array}$ & 2 & " \\
\hline II & 3 & 1) & $\begin{array}{l}\text { discoid lupus } \\
\text { photosensitivity }\end{array}$ & 2 & " \\
\hline II & 4 & & $\begin{array}{l}\text { discoid lupus } \\
\text { arthritis }\end{array}$ & 2 & " \\
\hline II & 5 & 1) & $\begin{array}{l}\text { discoid lupus } \\
\text { alopecia }\end{array}$ & 2 & " \\
\hline II & 6 & $\begin{array}{l}\text { 1) } \\
\text { 3) }\end{array}$ & $\begin{array}{l}\text { discoid lupus } \\
\text { facialerythema } \\
\text { photosensitivity }\end{array}$ & 3 & possible SLE \\
\hline $\mathbb{I I I}$ & 7 & $\begin{array}{l}\text { 1) } \\
\text { 2) } \\
\text { 3) }\end{array}$ & $\begin{array}{l}\text { discoid lupus } \\
\text { facial erythema } \\
\text { arthritis }\end{array}$ & 3 & " \\
\hline III & 8 & 1) & $\begin{array}{l}\text { discoid lupus } \\
\text { photosensitivity }\end{array}$ & 2 & non SLE \\
\hline III & 9 & $\begin{array}{l}\text { 1) } \\
\text { 2) } \\
\text { 3) }\end{array}$ & $\begin{array}{l}\text { discoid lupus } \\
\text { arthritis } \\
\text { alopecia }\end{array}$ & 3 & possible SLE \\
\hline III & 10 & 1) & $\begin{array}{l}\text { discoid lupus } \\
\text { leucopenia }\end{array}$ & 2 & non SLE \\
\hline N & 11 & $\begin{array}{l}\text { 1) } \\
\text { 2) } \\
\text { 3) }\end{array}$ & $\begin{array}{l}\text { discoid lupus } \\
\text { facial erythema } \\
\text { chronic BFP }\end{array}$ & 3 & possible SLE \\
\hline IV & 12 & 1) & $\begin{array}{l}\text { discoid lupus } \\
\text { facial erythema } \\
\text { alopecia }\end{array}$ & 3 & " \\
\hline IV & 13 & $\begin{array}{l}\text { 1) } \\
\text { 2) } \\
\text { 3) }\end{array}$ & $\begin{array}{l}\text { discoid lupus } \\
\text { arthritis } \\
\text { LE cells }\end{array}$ & 3 & " \\
\hline IV & 14 & $\begin{array}{l}\text { 1) } \\
\text { 3) } \\
\text { 5) }\end{array}$ & $\begin{array}{lll}\begin{array}{l}\text { discoid lupus } \\
\text { alopecia }\end{array} & \text { 4) } & \begin{array}{l}\text { arthritis } \\
\text { cellular casts } \\
\text { leucop enia }\end{array}\end{array}$ & 5 & definite SLE \\
\hline IV & 15 & $\begin{array}{l}\text { 1) } \\
\text { 3) } \\
\text { 5) } \\
6)\end{array}$ & $\begin{array}{l}\text { discoid lupus 2) arthritis } \\
\text { alopecia } \\
\text { photosensitivity } \\
\text { profuse proteinuria }\end{array}$ & 6 & definite SLE \\
\hline
\end{tabular}

Grade I were of non SLE; only one case was of possible SLE and the remaining three cases were of non SLE in Grade II; In Grade III, half of cases were non SLE and the remaining possible SLE.

In Grade IV, three cases were of possible SLE, and two cases with marked generalization of skin lesions, No. 14 and No.15, fulfilled more than four parameters in the criteria for the diagnosis of SLE and were diagnosed as SLE clinically.

\section{DISCUSSION}

An argument on the relationship between DLE and SLE has been made repeatedly since the diagnosis of LE was made only from the standpoint of pure dermatology.

With the remarkable progress in immunology in recent years, the pathogenesis of SLE has been elucidated increasingly. However, the true pathology of DLE still remains 
obscure in many respects and therefore, it has been discussed whether the two should be regarded as entirely other diseases or should be an identical disease differing only in the severity. The concept that DLE and SLE are essentially an identical disease is based on the reports that some cases of SLE are often presented with skin lesions for DLE and that there exist many cases of SLE developing into DLE or vice versa at a rather high incidence.

When discoid lesions are observed in SLE, there are reportedly three instances, namely, (1) discoid were followed by SLE $\left(3.0 \%{ }^{17)}-9.8 \%^{20221)}\right.$ of DLE, $10.8 \%^{22)}-26 \%{ }^{25)}$ of SLE) ${ }^{2)}$, SLE develops in association with discoid lesions $\left(18.2 \%^{9)}-33 \%^{12)}\right.$ of SLE) and (3) discoid lesions appear when SLE has subsided and become inactive $\left(13.3 \%{ }^{20)}-28.6\right.$ $\%^{22)}$ of SLE), and skin lesions often show those of W-DLE in all of the cases. Meanwhile, CANEON \& CURTIS ${ }^{3)}$, HERMANN et al. ${ }^{8)}$ reported that the shifting of DLE to SLE is very rare and they showed the incidence to be 1.3 percent and 0.76 percent respectively. MARTEN \& BLACKBURN ${ }^{14)}$ also made observations on L-DLE of 66 cases and W-DLE of 6 cases, stating that the development from DLE to SLE was not found out despite that abnormal laboratory findings were observed at a considerably high incidence in DLE. ROWELL ${ }^{19)}$ also made observations on clinical features and results of laboratory examinations for 120 cases of DLE and 40 cases of DLE over 12 years and reported that only two out of 120 cases developed into SLE. On the basis of results of statistical analysis of sex ratio and age of onset in patients with DLE and SLE, BURCH \& ROWELL ${ }^{122)}$ suggest that DLE and SLE would be other diseases with different hereditary background. MIZUMOTO et al. ${ }^{15)}$ gathered 153 cases from 72 familiar incidence of LE from documentary records all over the world and made a statistical survey to find that the incidence occured at $45.3 \%$ for a combination of SLE and SLE, 32\% for DLE and DLE and 22.2 $\%$ for DLE and SLE. From this survey, they concluded that DLE and SLE would be closely related to each other and that the two would have the identical hereditary background but develop under the influence of many factors.

In our study, LE was divided roughly into 3 types, namely, L-DLE, W-DLE and SLE, and a comparative study was made on the clinical features and laboratory findings for each type of disease. W-DLE was more close to L-DLE than to SLE in terms of the sex ratio and age of onset ${ }^{5(6) 12) 17) 23) 24) . ~ S k i n ~ m a n i f e s t a t i o n s ~ s u c h ~ a s ~ a l o p e c i a, ~ p h o t o s e n s i t i v i t y ~}$ and Raynaud's phenomenon characterized by LE were observed at about the same occurrence in all of these three type- ${ }^{5 / 6)(6) 17) 18) 20) 22) 23)}$; however, Raynaud's phenomenon was not found at all in our cases.

General symptoms such as fever, arthralgia and malaise are observed not only in SLE but in DLE as well(5)67)(12)14)16)17)18)23)24) but the incidence thereof becomes higher in the order of L-DLE, W-DLE, SLE.

In our cases of clinical trial there was a tendency for the incidence of these general symptoms to increase in proportion to enlargement of discoid lesion. Laboratory findings exhibited leucopenia, elevated ESR, hypergammaglobulinemia at a considerably high incidence in SLE as well as $\mathrm{DLE}^{5 / 6) 7(12) 1416) 17(18) 23 / 24)}$, but the incidence likewise becomes higher in the order of L-DLE, W-DLE, SLE. However, the occurrence of LE-cell test, 
LE test and chronic positive BFP, is very low in DLE and even in W-DLE compared with SLE. The histopathology of skin lesions in W-DLE resembles closely that of L-DLE in Grade I-II and with the development of Grade it is proved to be similiar to that of SLE. From the result of our studies, W-DLE has a tendency to resemble SLE closely as skin lesions enlarge. However, W-DLE appears to be more or less different from typical SLE in the age of onset, therapeutic effects, prognosis and incidence of positive LE cell. Of the cases of W-DLE, there certainly are cases which fulfill diagnostic criteria for SLE and can be diagnosed as SLE clinically; there is no case that alters from L-DLE to SLE immediately, but W-DLE intermediates between those two type of disease.

From these facts, it is suggested that W-DLE is a part of the spectrum of DLE and therefore is of the intermediate type between L-DLE and SLE.

When three types of LE is examined from the aspect of main affected organs, LDLE may be regarded as LE of which lesions are localized only to the skin, W-DLE as a type in which the skin and a part of other organs are affected and SLE as a type in which many organs including the skin are affected systematically. And each type of disease is presumed to be determined by many factors such as hereditary predisposition, various exogenous factors and immunological defense mechanism of the individual body. The skin will play an important role as a target organ common to these three types of disease.

For the true pathology of LE to be elucidated, however, more detailed immunoserological and immunohistochemical examinations on large number of additional cases of W-DLE would be a major subject for future study.

\section{ACKNOWLEDGEHEUT}

The authors wish to thank Professor MICHIO NOGITA in the Department of Dermatology, Nagasaki University School of Medicine for this helpful advices and guidance in this study. 


\section{REFERENCES}

1) Burch, P. R. J. : Lancet II : 507, 1963.

2) Burch, P. R. J. and Rowell, N. R. : Amer. J. Med. 38: 793, 1965.

3) Cannon, E. F. and Curtis, A. C. : Arch. Derm. 78: 196, 1958.

4) Conen, A. S. and CANoso, J. J. : Criteria for the classification of systemic lupus erythematosus-Status 1972. Arth. Rheum. 15: 540, 1972.

5) Dubors, E. L. : Lupus Erythematosus, p.277-292. Mc Graw-Hill, New York,1966.

6) Epstein, J. H. and Tuffanelli, D. L. : Lupus Erythematosus p.114-128. Mc Graw-Hill, New York, 1966.

7) Furuy a, T. : Jap. J. Clin. Med. 26: 3366, 1968. (in Japanese).

8) HerrmanN, W. D. et al. : Hautarzt. 13: 309, 1962.

9) Hamaguchi. T. : Rinsho Derma (Tokyo) 6: 782, 1964 (in Japanese).

10) Hara. N. : Jap. J. Dermat. 79: 823, 1969. (in Japanese).

11) Lever, W. F. : Histopathology of the Skin, 4th ed. P451-462, Lippincott, Philadelphia, 1967.

12) Montgomery, H. and Mc Creight, W. G. : Arch. Derm. 60: 356, 1949.

13) Michelson, A. Y. : Arch. Derm. 65: 1, 1952.

14) Marten, R. H. and Blackburn, E. K. : Arch. Derm. 83: 430, 1961.

15) Mizumoto, T and Takashima, I. : Jap, J. Clin Dermat. 22: 883, 1968. (in Japanese).

16) Pascher, F. : Handbuch d. Haut u. Geschlechtskrankheiten, Jadassohn, II/2, p.440, Springer-Verlag. Berlin, 1965.

17) Rothfield, N. F. :and MARCh, C. H. : New Eng. J. Med. 269: 1155, 1963.

18) Rothfield, N. F. and MARCh, C. H. : Dermatology in Internal Medicine, ed, by Fitzpatrick, p.1493-1518. Mc Graw-Hill, New York, 1971.

19) Rowell, N. R. : Br. J. Derm. 84: 210, 1971.

20) Scott, A. and Rees, E. G. : Arch. Derm. 79:422, 1959.

21) Storck, H. and BerzuPs, S. : Dermatologica. 124:142, 1962.

22) Tuffanelli, D. L. and Dubos, E. L.: Arch. Derm. 90: 377, 1964.

23) TANiokU, K. : Clin. Immunol. 5: 137, 1973. (in Japanese).

24) UEKI, H. : Clin. Immunol. 1: 595, 1969. (in Japanese).

25) Wilson, A. P. and Jordan, J. W. : New York J. Med. 50: 2449, 1950. 